\title{
Analysis of Threats to Economic Security of Lithuania
}

With reference to research as well as legal and statistical data, this article offers an interpretation of the "security" concept, perception of country's security, and analysis of drafting a national security strategy. It also highlights constituent parts of a national security strategy and an economic security strategy within the context of national strategies. Moreover, it shows how decisions (both operational and strategic) that are made within the context of national strategies depend on the relevance and probability of manifestation of threats. A motivated conclusion is drawn that a strategy for economic security is a constituent part of an economic strategy.

The composition of threats to economic security is further revealed by showing that threats can be both external and internal.

The article also exposes the relationship between an economic policy and economic security guarantees.

In addition, it identifies threats to the economic security of Lithuania and performs their analysis. It defines factors that predetermine the change of indicators of economic security by revealing the indicators themselves.

The analysis of threats to economic security is practically impossible without the context of an economic security strategy, or this analysis would be incomplete in a methodological sense. On the other hand, the author does not claim to provide a comprehensive analysis of threats to economic security.

\section{Introduction}

Recent processes of integration and globalisation return us to the strategy for economic security and both internal and external threats to economic systems of nation states which arise from the strategy ${ }^{1}$.

A country's economic security depends on the efficiency of functioning of its economic system and, in this sense, there is a direct correlation between the rate of economic growth and degree of economic security. On the other hand, this correlation can be directly applied only to the internal threats to economic security, while indirectly it can be applied to external threats. As history witnesses, the post-war

${ }^{\text {"Doc., }}$ dr. Artūras Grebliauskas - Associate Professor of the Faculty of Business and Management of the Kaunas Vytautas Magnus University, Address: Donelaičio 20, LT-3000 Kaunas, Lithuania, tel. +370-687-85643, e-mail: efargr@fc.vdu.lt

${ }^{1}$ For more information on the impact of globalisation on nation states, see Scholte Jan Aart., Globalisation. A Critical Introduction, London, Macmillan Press Ltd, 2000, Daniels P.W., Lever W.F., The Global Economy in Transition, London, Addison Wesley Longman Limited, 1996., Held D., McGrew A., Goldblatt D., Perraton J., Globaliniai pokyčiai: politika, ekonomika ir kultūra, Vilnius, Margi raštai, 2002. [Global Transformations Politics, Economics and Culture]. 
economic crises were mostly provoked by external threats on the one hand, and failure of national economic systems to adjust to a new environment on the other. The main external influence, as a rule, was a sudden change in the price of raw materials and expectations of economic entities.

The object of research of the article is threats to a country's economic security and how they originate.

The article aims at performing the analysis of threats to country's economic security. From a methodological point of view, such an analysis covers:

pretation of the concepts "security," "national security," "economic security," "security of an economic entity," and "security of a human being";

ting up of goals of an economic security strategy within the goals of a general national security strategy; ex a -

mination of the composition and manifestation of threats to economic security;

The first part of the article deals with the definition of economic security, reveals the strategy for economic security and its place within the context of a general national security strategy. It also shows compatibility of the goals included into the strategies in question, hierarchy of goals, and the degree of centralisation/decentralisation of a decision making process. The second part focuses on the identification of the composition of threats to economic security and offers the classification of threats. From a methodological point of view, threats are understood as a part of SWOT analysis which is generally used in a strategic analysis ${ }^{2}$. The third part offers a synthesis of the first and the second parts, i.e. the results of the analysis are interpreted taking into account the goals of economic security and a national security strategy.

\section{Economic Security Strategy}

\subsection{Interpretation of the "Security" Concept}

The analysis of the "security" concept can be conducted on three levels ${ }^{3}$, i.e. that of a state, an economic entity and a human being. The security of the state dominates the security of an economic entity and a human being. In the face of threat, the state will employ all its resources to ensure its security without considering the security of an economic entity and a human being. Such a hierarchy of security matches with hierarchy of threats in a decision-making process, since the former has to respond to the threat to national security in emergency situations, and the needs of an economic entity and a human being might be ignored.

Evidently, each level of security (that of a state, an economic entity, and a

\footnotetext{
${ }^{2}$ It is better to use the concept of "risk" in the analysis of economic security of the state as the concept is wider within the context of SWOT analysis. Other methodology, i.e. the so-called PEST analysis, could be used in identifying and detailing fields of the analysis, which cover legal environment, economic environment, socio-cultural environment and technological environment. Furthermore, threats are identified and SWOT methodology is applied for a more detailed examination. ${ }^{3}$ Similar levels of security were also singled out by Buzan, B. in the book Žmones, valstybess ir baimé: tarptautinio saugumo studijos po šaltojo karo. (Buzan B., Žmonès, valstybés ir baimé: tarptautinio saugumo studijos po šaltojo karo [People, States and Fear: An Agenda for International Security Studies in the Post-Cold War Era], Vilnius: Eugrimas, 1997.).
} 
human being) has the object and subject of the security system. The object is the target for the subject to act in order to ensure its (object's) security. Subjects are institutions which ensure the security of the object. It is understandable that referring to economic security of the state we have in mind material, intellectual, and cultural grounds which are simultaneously the basis for satisfying economic needs. Therefore, the object of economic security of the state is the economic system of the state.

"Economic security is not only protection of national interests, but also readiness and capacity of public authorities to establish a mechanism for realisation and protection of national interests while developing national economy and maintaining socio-political stability within the society". ${ }^{4}$ This definition places more emphasis on the internal potential of the state and the role it has to play. In other words, the emphasis is put on the institutional structure of the state and its capacities.

The Russian academician L.I. Abalkin states that "economic security is the totality of circumstances and factors which ensure independence, stability, and capacity of consistent renewal of the national economy."

According to A. Ilarionov, Director of the Institute for Economic Analysis, "economic security of the country is such a combination of economic, political and legal conditions which will ensure maximum quantities of reproduction of economic resources per capita in a long run and in the most efficient way". ${ }^{6}$ Such a presentation of the concept leads to the conclusion that one of the key indicators of economic security is the level of economic development and economic growth. Therefore, the key goal is to ensure economic growth. On the other hand, guarantees of economic growth play a decisive role in the economic security of the country. In other words, according to this definition, key problems and key actors arise from the economic policy or the domestic situation of the state.

The Lithuanian National Security Strategy ${ }^{7}$ attributes economic security to primary interests. One of them is "ensuring alternative energy supplies and supply of resources that are of strategic importance". "Primary interests. These are the interests that could eventually affect the vital interests of the Republic of Lithuania if not protected". Further description in the strategy of challenges, dangers and threats explains that:

"overwhelming dependence of the Republic of Lithuania on strategic resources and energy supplies of one country or the concentration of foreign capital representing economy, in which free market is not secured or unstable, in one or several economic sectors of strategic importance to national security is a potential danger not only for economic prosperity but also for the security of the country.

\footnotetext{
4 Экономическая безопасность: Производство - Финансы - Банки [Economic Security: Manufacturing, Finance and Banks]// Под ред. В. К. Сенчагова - М.: ЗАО "Финстатинформ", 1998. С. 12.

${ }_{5}^{5}$ Абалкин Л. И., Экономическая безопасность Россий: угрозы и их отражение [Economic Security of Russia: Threats and Their Reflections]// Вопросы экономики, 1994, Но. 12, стр. 4 - 13 .

${ }^{6}$ Илларионов А. Критерии экономической безопасности [Criteria of Economic Security]// Вопросы экономики, 1998, Но. 10, стр. 49.

${ }^{7}$ Resolution of the Seimas of the Republic of Lithuania on the Approval of the National Security Strategy. 28 May 2002, No. IX - 907. "Valstybès žinios" (Lithuanian Official Gazette). 7 June 2002, No. 56. pp. $28-29$.
} 
tain economic conditions may constitute dangers to the security of the Republic of Lithuania, the well-being of its population, the independence of the state or constitutional order. These could be the following:

cession of assets and control over sectors and objects of strategic importance to national security, while pursuing political goals, as well as acting in a manner that violates economic security;

infe-

rior functioning of economic and energy sectors and deranged functioning of the objects that are of strategic importance to national security, their improper usage or non-usage, interfering with the interests of the state.

-

ven social and economic development that increases a gap in living standards between different social groups may present a dangerous condition.

$$
\text { - }
$$

Acti-

vities of groups of organised and financial crime constitute a major threat to the state and society."

The provisions of the National Security Strategy and the guidelines for its implementation also emphasise "stable economic growth. A strategic priority for the national security of the Republic of Lithuania is the formation of conditions for economic growth so as to ensure a higher quality of life for its citizens". "General resource priorities: with regard to distribution of resources in the various areas that directly affect overall security of the Republic of Lithuania, priority is given to activities that enhance economic growth, social stability, fostering of civil society and threat response capabilities with particular attention to activities associated with integration into NATO and the EU". ${ }^{8}$ The main actions and means for implementing the National Security Strategy in the field of economic security identify the following key factors:

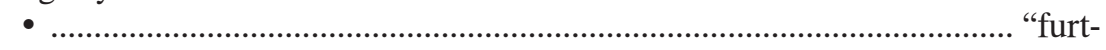

her implementation of structural reforms;

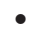
assurance of conditions of macroeconomic stability;

tion of favourable environment for the investment and business, benefitial to economic development;

$$
\text { -...... }
$$
i m plementation of employment policy, encouraging small and medium-sized business and regional development;

$$
\bullet
$$
port incentives;

\footnotetext{
${ }^{8}$ Resolution of the Seimas of the Republic of Lithuania on the Approval of the National Security Strategy. 28 May 2002, No. IX - 907. "Valstybės žinios" (Lithuanian Official Gazette). 7 June 2002, No. 56. p. 30.

${ }^{9}$ Ibidem, p. 34.
} 
tablishment of obligatory energy reserves;

assu-

rance of stable fiscal and monetary policy;

versification of energy supply sources;

paration of the economic infrastructure and transport for operating under extreme and critical conditions." $"$

Although the National Security Strategy does not provide for a compact definition of economic security, it offers an understanding that the key goal of economic security is to ensure functioning and development of the economic system by the state.

The author believes that the economic security of the country should be defined as the capacity (i.e. political will, possibility, and ability) of the state and its entities to maintain the balance between economic objects and systems, which is the key (necessary and sufficient) precondition for extended development of the state and its entities. On the other hand, goals of maintaining the balance are, as a rule, linked with the external environment of the system. This means that the economic security of the state should be understood as its capacity, as well as the capacity of its entities to maintain the balance between economic objects and systems and simultaneously react to the external environment. The internal environment of the system, as a rule, shows the potential of the system which ensures efficiency of the response to the external environment.

Thus, the essence of economic security can be defined as the state of government and economic institutions, which ensures strengthening of their internal potential and the development of the country.

\footnotetext{
${ }^{10}$ Grebliauskas A., "Regulation of the National Currency Exchange Rate in a Small and Open Economy", Finances and Credit: Problems, Conceptions, Management: Scientific Papers. Riga: University of Latvia, 2001, Vol. 644. pp. 193 - 204. The article examines causes why small countries with open economies most often choose a fixed exchange regime. Several interrelated elements can be noted, i.e. a small economy, open economy, liberal trade regime and fixed exchange regime. It is understandable that these characteristics significantly predetermine the content of both internal and external threats and the structure of their lists.
} 


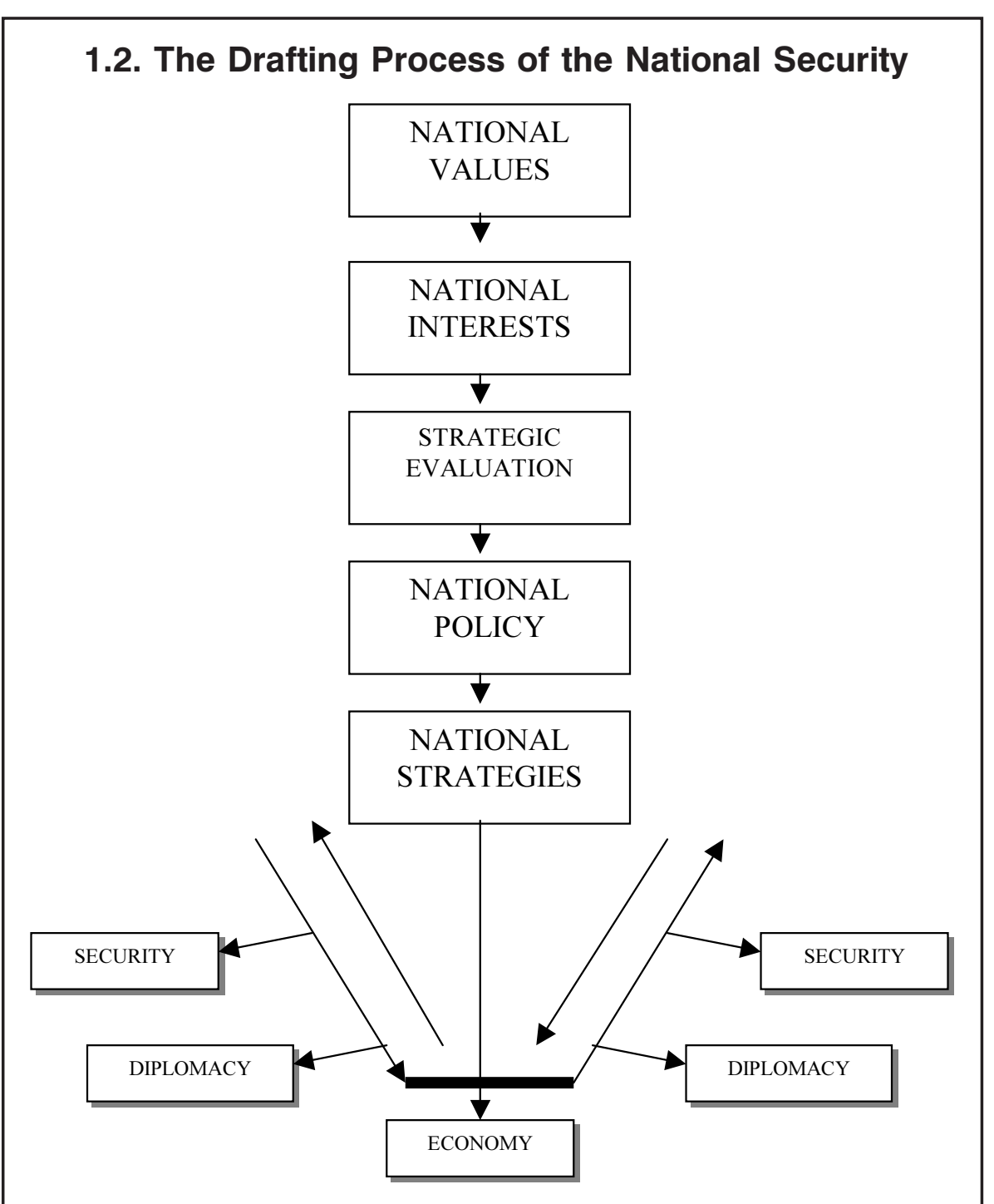

\section{Strategy}

Lithuania has the following characteristics that are typical of small countries and predetermine national strategies, the list of economic threats and their content:

- Lithuanian economy is a small economy and this predetermines that Lithuanian economy is an open economy with a liberal trade regime $;^{10}$

- Lithuania has a fixed exchange regime;

- Favourable geographic location that allows to enjoy the status of a logistic third party;

${ }^{11}$ The figure was drafted by the author with reference to Yarger R.H., Barber G.F., "The U.S. Army War College Methodology for Determining Interests and Levels of Intensity," Carlisle Barracks, PA: U.S. Army War College, 1997, pp. 1 - 12. 
- Lithuania has insufficient mineral resources or their industrial exploitation is too expensive.

Figure 1 reveals the context of the drafting process of the national security strategy.

Each national strategy is formulated on the basis of the assessment of national values in view of the international context. These values allow for better understanding of national goals, which should be reflected in the basic document, i.e. the constitution.

\section{Figure 1. Process of Strategic Thinking ${ }^{11}$}

Nations have interests that are based on their (national) internal values and realised goals which motivate their behaviour. Thus, national interests reveal a nation's needs and wishes within the international context. National interests of the state define its partaking in global developments. They also define the course of actions of the state in identifying goals and drafting national policy and national strategies.

Strategic evaluation includes the analysis of internal and external conditions in an attempt to define powers and trends that influence national interests, as well as possibilities and threats related to national strategies.

In order to protect national interests political actors formulate political principles which define the process of drafting national strategies. Thus a national policy sets a general direction for actions on a state level to ensure protection of national interests.

The author thinks that there are three key national strategies, i.e. those of national security, foreign policy (or diplomacy) and economy. Although some authors tend to single out more of them, ${ }^{12}$ other strategies can be considered as derivatives. This gives rise to one of the most essential questions: which national strategy has an economic security strategy as its derivative? Although an economic security strategy should not contradict a national security strategy, it is derived from an economic strategy. The main argument behind this is the context of its goals, processes and resources, which shows the general pbject of these strategies - an economic system. It is understandable that it should be palanced both horizontally and vertically. Moreover, economic security includes finance. energy, defence, military industry, information, and food supply security.

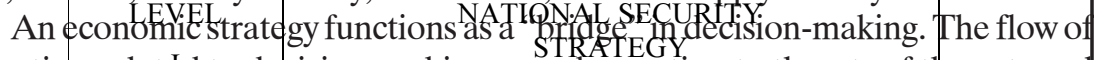
information related to decision-making reveals reaction to threats of the externa

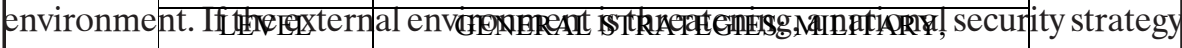

\begin{tabular}{|c|c|}
\hline II & ECONOMIC, DIPLOMATIC, SOCIAL \\
\hline LEVEL & OPERATIONAL STRATEGIES \\
III & \\
\hline
\end{tabular}

\footnotetext{
${ }^{12}$ In his overview of the evolution of the strategy concept, V. Urbelis singles out 4 general strategies, including social, military, economic, and diplomatic. It is understandable that if the state strives for the status of a welfare state, a social strategy also becomes one of the most important. Referring to other authors, he specifies a holistic strategy, which in practice is identical to a national security strategy, and to the aforementioned 4 general strategies on the secondary level, and strategies, i.e. activity measures (laws, staff, materials, technologies, organisation, etc.) that are attributed to the operational level, on the tertiary level. Urbelis V. "Strategija - jos evoliucija ir $\mathrm{s}^{1}$ vokos evoliucija" ["Strategy - Its Evolution and Evolution of Its Concept"] Politologija. 2001. No. 4. pp. 53 - 81.
} 
becomes a prevailing strategy and then all possible means and resources should be employed for attaining the goals of the national security strategy. Firstly, diplomatic means which are based on economic capacity should be also used to this end. It diplomatic channels fail, it remains to rely on resources available (both inside and outside the country). See Figures 1 and 3.

If the external environme GENERAL NATIONAL petition appears among the political allies of democrat $\quad$ STRATEGIES $\quad$ th a relationship (poli-

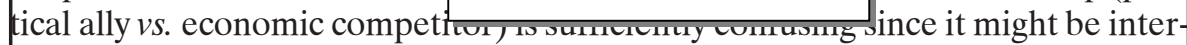
preted differently, depending on which approach (industrial, post-industrial, geo-

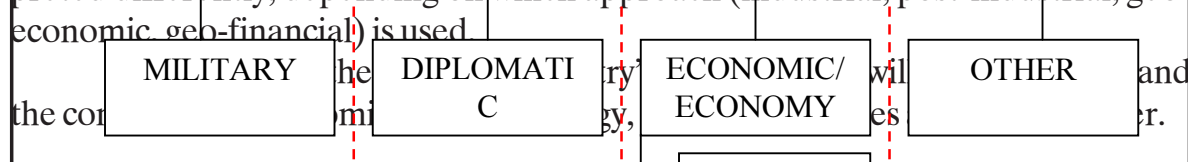

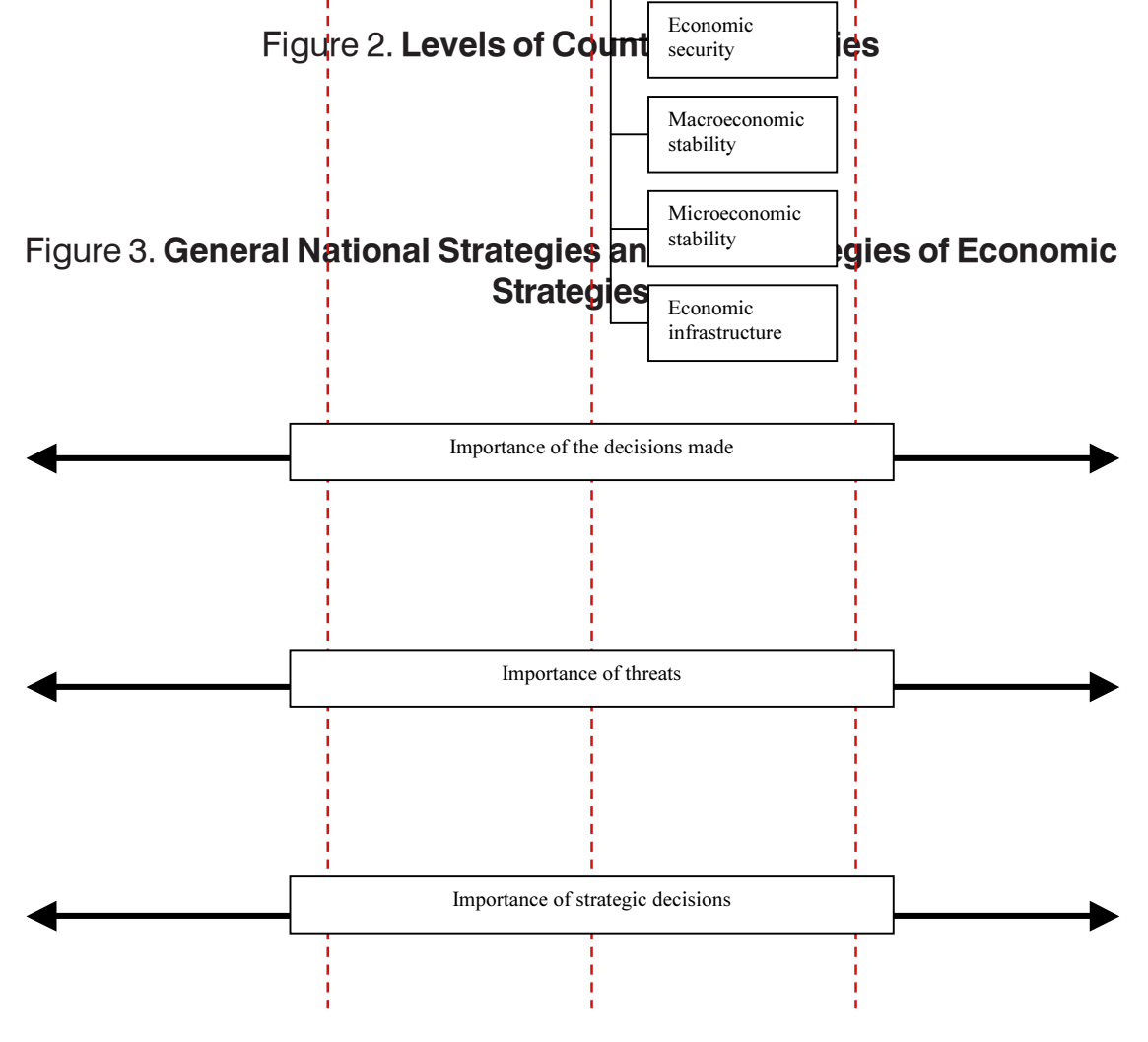

High 
High

Low

High

Low

Military Diplomatic Economic Other

Economic sub-strategies are interrelated, since the key goals of macroeconomic stability are to ensure a constant growth of economy, reduction of the unemployment rate, low rate of inflation, stability of the exchange rate, and a foreign trade balance.

A microeconomic stability strategy has to ensure free capital flows from sector to sector, mobility of labour force, etc.

Economic infrastructure is known to cover energy, transport, communications, telecommunications, utilities, waste management, etc. The key goal of this strategy is to ensure undisrupted economic development. Sectors of the infrastructure are usually natural monopolies which cover the entire country by their activities; therefore, their efficient work is vital in the sense of economic security. Namely, that is why these sectors are important for the country and its economic development.

It is understandable that threats (their intensity, scope and dynamics), strategies and decision-making processes are interrelated. The centralisation (importance) or decentralisation of the decisions made depends on the framework of their adoption. It is important to establish their relation with external and internal environments, as the latter are known to give rise to external and internal threats.

\section{Threats to the Economic Security of the Country}

\subsection{Composition of Threats to Economic Security}

Strengths and weaknesses, opportunities and threats of the economic potential of the country are revealed with the help of the following aspects of a strategic analysis $^{13}$ :

- geographical situation, natural and material resources of the country;

- level of education and vocational training of people;

- production potential and technical level of technology: industry, agriculture, construction;

\footnotetext{
${ }^{13}$ A similar list is offered by A. Vasiliauskas in the article "Lietuvos ekonomikos pletros strategijos kūrimo ir igyvendinimo metodologiniai principai" ["Methodological Principles of Building and Implementation of the Lithuanian Economic Development Strategy"], Pinigu studijos, Lietuvos bankas, 2000, No. 4. The point is that such a list has to be compiled in view of the possibilities offered by PEST methodology. SWOT analysis in specific areas follows only after PEST analysis. In our case, this represents economic threats, although they are linked to other parts of SWOT analysis.
} 
- material infrastructure: energy, transport, distance communications, utilities;

- economic-financial infrastructure: banks, commodity exchange, stock exchange, insurance;

- macroeconomic situation of the country: economic growth, structure of economy, employment, inflation, balancing the national budget, public debt, stability of the currency;

- international economic relations of the country: foreign trade, competitive capacity of the country on foreign markets, foreign investments and investments abroad, balance of payments, foreign debt;

- economic policy of the state.

It would be possible to single out the following key economic threats:

- threat of structural deformation;

- threat of decrease in the rate of investment and innovation activities;

- threat of "destruction" of scientific - technical potential;

- threat of dependence on import;

- threat of dependence on the supplier of strategic raw materials;

- threat of decrease of currency reserves;

- threat of the growth of public satisfaction;

- threat of the growth of foreign debt;

- threat of the growth of domestic debt;

- threat of corruption in economic relations.

Naturally, the list of threats changes depending on the degree of openness of the economy. Following the reasoning of the theory of systems, the more open the economy is, the less threats to national economy might appear. ${ }^{14}$ However, it is relevant with only one essential precondition. The external environment of a national economy should be "friendly". On the contrary, where it is not the same system theory states that the system in question will try to "close" itself from the adverse external environment.

\subsection{Internal and External Threats}

The national policy of a country is usually twofold: internal and external ${ }^{15}$. Thus, its economic policy is also reflected internally and externally. Therefore, threats can be classified into internal and external.

The manifestation of internal threats can be defined as incapacity to ensure safety and development, weakness of an innovative factor, ineffective state regulation of economy, incapacity to establish optimal balance of interests and inability to solve

\footnotetext{
${ }^{14}$ What is kept in mind is Lithuania's membership of the EU and NATO and that Lithuanian economy functions experiencing threats which arise only as a result of the competition with other countries. There is no threat of a war or a military conflict, or, in other words, there is no threat of a political nature.

${ }_{15}$ Although lately publications appeared both in Lithuania and abroad, such a division under globalisation loses its sense. Therefore, it is increasingly difficult to separate country's domestic and foreign policies. Strange S. Valstybes ir rinkos [States and Markets], Vilnius, Eugrimas, 1998. Gilpin R. Tarptautiniu santykiu politine ekonomija [Political Economy of International Relations], Vilnius, Algarve, 1998, Hollis M., Smith St. Tarptautiniai santykiai: aiškinimas ir supratimas [Explaining and Understanding International Relations], Vilnius, Tyto alba, 1998.
} 
social contradictions and conflicts.

Based on the reasoning of strategic management, we can state that long-term "maintenance" of internal threats negatively affects the internal potential of a country and makes the country more vulnerable to external threats. First and foremost, this means that an internal economic threat impedes the retaining of the country's status in the world. Secondly, the economic weakness of the state makes the government borrow from international financial institutions. Thirdly, the dependence of the country on imports increases. Fourthly, the state loses its capacity to carry out an active foreign policy.

Internal threats mostly manifest themselves in macroeconomic and microeconomic sectors and infrastructure.

External threats can be described as an objective phenomenon, and the incapacity of the state to react adequately to a change of external environment: dynamics of competition, change in price of global conjuncture, dynamics of supply of strategic raw materials can be treated as subjective. I have already referred to inadequate reaction which is predetermined by the internal potential of the country. The relation in this case is as follows: the internal economic potential of the country predetermines its response to external threats and participation in the process of earning "global income".

External threats are relatively better manifested in foreign economic activity. I have already mentioned that external threats are threats solely for the fact that the internal potential of the country is too weak to withstand the pressure of external threats and, therefore, the earlier listed essential economic threats may manifest themselves.

In order to avoid the manifestation of economic threats, it is necessary to ensure the growth of country's economy. "Economically independent" are those countries that have been able to ensure their economic growth. This is proved by the analysis which was carried out by the Institute for Economic Analysis in Russia. ${ }^{16}$

Therefore, further analysis leads to the examination of economic policy of the state and its constituent parts, such as participation of the state in business - entrepreneurship of the state, fiscal policy, monetary policy, foreign economic policy and its component - foreign trade policy.

The participation of the state in business reveals a trend which can be identified as the dependence of the rate of the economic growth on the volume of the gross domestic product (GDP) created by state property, i.e. the more GDP is created by state property the slower is its economic growth. ${ }^{17}$

Fiscal policy singles out current public consumption, public investment, budget deficit, and public debt. The point is that the bigger the current public consumption, public investment, budget deficit, and public debt are in comparison to the GDP, the slower the rate of economic growth is. ${ }^{18}$ The evaluation of public consump-

\footnotetext{
${ }^{16}$ Илларионов А. "Критерии экономической безопасности”' [Criteria of Economic Security], Boпросы эКономики, 1998, Но. 10, стр. 49 - 58.

${ }^{17}$ Ibidem, p. 51.

${ }^{18}$ Ibidem, p. $52-54$

${ }^{19}$ Ibidem, pp. $54-55$.

${ }^{20}$ Ibidem, p. 56.
} 
tion and public investment calls for the attention to the existence of two-tier indicators, i.e. the minimum rate of public expenditure (current consumption and investment) which ensures performance of necessary functions of the state and the maximum rate which, if exceeded, significantly decreases the rate of economic growth. Thus, the minimum and the maximum rates are highly dependent on certain historical development of the state, general global trends, etc.

In the sense of economic security, monetary policy is very important in solving the ways of financing the budget deficit. In countries where the average velocity of the currency in circulation, excluding the growth rate of real GDP, does not exceed 3 per cent, the rate of the economic growth is the highest. Providing other circumstances remain equal the increase of the scale of currency issue predetermines a slowdown in the rate of economic growth. ${ }^{19}$

Taking into account that the dynamics of currency in circulation are related to the dynamics of inflation, the dependence of the rate of economic growth on the rate of inflation is of a similar nature. Generally, the maximum speed of economic growth is achieved when the average annual inflation is maintained under 3 per cent. ${ }^{20}$ With an increase in the rate of inflation, the rate of economic growth slows down as a rule. When the average annual inflation fluctuates hetween $40-100$ per cent, the econo-

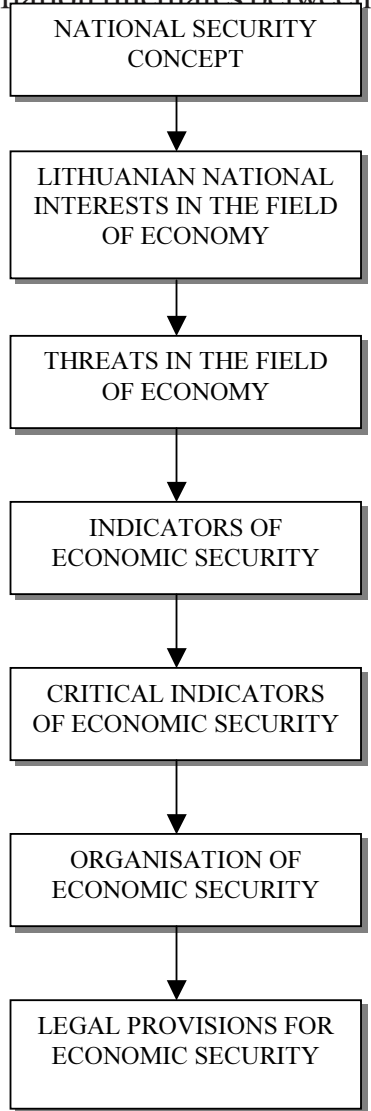

${ }^{21}$ Ibidem, p. 56

${ }^{22}$ The scheme of an economic security system was compiled by the author. 
mic growth stops.

Moreover, there is a relation between the economic growth and currency devaluation. The study carried out by the Institute for Economic Analysis concludes that "the maximum rate of GDP growth between 1991 and 1996 occured in those countries where the price of their currencies was not curtailed and grew in value in comparison to the USD". ${ }^{21}$

The existence of the relation between foreign trade policy and economic growth is illustrated by the fact that the economy of countries with a liberal trade regime grows at a higher rate than in countries imposing taxes on export and import turnover.

\section{Analysis of Threats to the Economic Security of Lithuania}

The system of the economic security of Lithuania derives from the process of the strategic administration of the state and covers the following blocks. See Figure 422

\section{Figure 4. System of the Economic Security of Lithuania}

The National Security Concept was approved by the Seimas of the Republic of Lithuania on 28 May 2002.23

Lithuanian national interests in the field of economy derive from or are legitimised in the Security Concept. On the other hand, a decade of Lithuanian independence is too short a period to arrive at a very clear definition of Lithuanian national interests in the field of economy. We are aware of the fact that almost all the time interests manifest themselves in foreign economic activities; it is also understandable that internal economic resources of the country are employed for pursuing the interests. Due to the said reasons, Lithuania, in my view, has not completed the formulation and legitimisation of its national economic interests. Nevertheless, such attempts are present in the field of economic policy. The Seimas determines by law which plants and facilities (including those to be established) are of strategic importance to national security. The law also sets forth which of them must be state property, and which of them (and under what circumstances) are allowed to attract private national and foreign capital which complies with European and transatlantic integration criteria, while the power of decision-making rests with the state.

The government must ensure alternative resources of fuel and raw materials that are not dependant on a monopolistic supplier. Supply with energy resources

\footnotetext{
${ }^{23}$ Resolution of the Seimas of the Republic of Lithuania on the Approval of the National Security Strategy. 28 May 2002, No. IX - 907. "Valstybès žinios" (Lithuanian Official Gazette). 7 June 2002, No. 56.

${ }^{24}$ Law on the Fundamentals of National Security of the Republic of Lithuania. 19 December 1996, No. VIII - 49. "Valstybės žinios" (Lithuanian Official Gazette). 1997. No. 2-16.

${ }^{25}$ Law of the Republic of Lithuania on Amendment to Articles 3 and 4 of the Law on Reorganisation of the AB "Būtingès Nafta", AB "Mažeikių Nafta," and AB "Naftotiekis". 2 August 2001. No. IX-480. "Valstybės žinios" (Lithuanian Official Gazette), 4 August 2001. No. 68-2469.
} 
cannot be transferred to the control of entities in supplier countries. Foreign investment that complies with European and transatlantic integration criteria is given preference. The predominant position of foreign economic entities in the sector of natural monopolies and finance sector is also prohibited.

Within their individual authority, the Bank of Lithuania, the Government and law enforcement institutions ensure protection of the economic and banking-financial system from fraud, money and investment of an unlawful origin.

After the completion of a special state programme, Lithuanian railways should be gradually reconstructed according to the European gauge standards. The system of transportation by Lithuanian railways should be restructured according to the norms of the Convention Concerning International Carriage by Rail (COTIF). ${ }^{24}$

On the other hand, these provisions are not applied to investment into the $\mathrm{AB}$ "Mažeikiu Nafta", since "the shareholding, management and supply with energy resources of the AB "Mažeikių Nafta" are solved without applying the restrictions set forth in Chapter 4 "Economic Policy" of Part 1 of the Annex "Fundamentals of National Security" of the Law on the Fundamentals of National Security". ${ }^{25}$ The Company "Yukos" invested into the AB "Mažeikiu Nafta" on the basis of the same terms and conditions as the Company "Williams" did before.

\subsection{Lithuania's Relations with Transnational Corporations}

The inconsistency of goals of the development of transnational corporations and nation states is an understandable and undisputable phenomenon. On the other hand, there is a considerable number of opinions on the issue of the impact that transnational corporations make on the development of nation states. ${ }^{26}$

This relation manifests itself in three aspects, i.e. 1) relations between a transnational corporation and a host country, 2) relations between a transnational corporation and the country of establishment, 3) relations between a host country and the country of establishment.

With respect to threats to economic security, the following three aspects are singled out as important. In this context we should talk about the goals of the development of "Yukos" and the state economic system of Lithuania. The development strategy of "Yukos" is based on increase in exports of crude oil and penetration into the markets of alternative energy resources (gas, power). Therefore, "Yukos" plans investments into the infrastructure of oil transportation in Europe, Asia, and Ameri-

\footnotetext{
${ }^{26}$ Vernon R., Multinationals are Mushrooming in King Ph., International Economies and International Economic Policy: a reader, USA, McGraw-Hill, Inc., 1990., King Ph., The Multinational Corporation: Pro and Con in King Ph., International Economies and International Economic Policy: a reader, USA, McGraw-Hill, Inc., 1990., Biersteker Th., Distortion or Development: Contending Perspectives on the Multinational Corporation, Cambridge, Mass, MIT Press, 1978, chaps. 1-3., Moran Th. H., "Multinational corporations and the developing countries: an analytical overview", in Th. H. Moran (ed.), Multinational Corporations, Lexington, Mass, Heath, 1985, pp. 3-24., Gilpin R., "Multinational Corporations and Global Production," in Gilpin R., Tarptautiniu santykiu politine ekonomija [Political Economy of International Relations], Vilnius, Algarvé, 1998, p. 284-318.
} 
ca and also buys shares of the Russian power system. How could Lithuania benefit from these "Yukos" actions? This is not a rhetorical question. "Yukos" has practically acquired the whole complex of oil transportation, refining, and realisation in Lithuania, except the oil terminal in Klaipeda. From the point of view of "Yukos" development strategy, the company will aim at acquiring Klaipeda Oil Terminal. Based on the same reasoning, it becomes evident that by controlling the pipeline on the territory of Lithuania, "Yukos" will be able to make an impact on the operation of Venspils Oil Terminal and probably on its privatisation.

In the sense of economic security, the situation of Lithuania is not the best one in this context. What is controlled by the state of Lithuania in this case? The question could be paraphrased. Should Lithuania maintain control in this situation? The answers will be fifty-fifty, depending on political and economic ideology. By establishing a supermarket of a Lithuanian origin, which in its own turn opened doors for Lithuanian suppliers to the Latvian market, is an evident example of investment by Lithuanian economic entities in Latvia. As a result, the Lithuanian national budget benefits and economy grows. In case of the investment into the Latvian market, Lithuanian economic security is enhanced, as the investment promotes economic growth, but the external risk, which may result in recession in certain industrial sectors, grows too.

\subsection{Factors Which Predetermine a Change of Indicators of Economic Security}

Within the last decade Lithuanian economy underwent fundamental changes: the level of economic openness and liberalisation grew significantly, the structure of the economy changed, a private sector established itself, and competition increased. Foreign investment plays an important role in modernising the economy. The EU integration is an ongoing process. With the rapid growth of foreign trade volumes, export is reoriented from the CIS to the EU market, which now makes up about 50 per cent of Lithuanian export. ${ }^{27}$

On the other hand, the growth of small countries characterised by small scale economies is predetermined by the integration and intensification of reproduction as an essential precondition for development. From the point of view of system comprehension in the field of economic security, the process or separate parts of the process of reproduction, integration and intensification of Lithuanian economy should be "included" into the global process of reproduction. An example of such a "law" in Lithuania is the transfer of the AB "Mažeikių Nafta" to the United States Company "Williams". Such a "law" increases the economic security of Lithuania. The sale of the AB "Lietuvos Telekomas" to a Scandinavian consortium is another example of equal value.

Lithuania has chosen a liberal trade regime and movement of capital. General liberalisation of trade has been significantly affected by signing free trade agreements (FTAs). The countries which have concluded FTAs with Lithuania account for 70 per cent of total foreign trade. In 2001, Lithuania became a member of the World

\footnotetext{
${ }^{27}$ Lithuanian Economic Pre-accession Programme, http://www.finmin.lt/liet/peppro.htm. 6 August 2002.

${ }^{28}$ Lithuanian Economic Pre-accession Programme, http://www.finmin.lt/liet/peppro.htm. 6 August 2002 .
} 
Trade Organisation.

The economy of Lithuania is marked with a low level of protectionism. In 2001 , import duties made up only about 0.3 per cent of GDP, and those on imported goods about 53.2 per cent of GDP.

The main trend which defines the development of trade flows is increasing volumes of trade with the EU and decreasing trade with the CIS. In 1996-2000, export of Lithuanian goods to the EU grew from 32.9 to 47.9 per cent and that to the CIS dropped from 45.4 to 16.3 per cent of total exports, and import grew from 42.4 to 46.5 per cent and from 32.9 to 30.7 per cent, respectively. ${ }^{28}$

The following main reasons of fiscal risks are forecasted: deposit insurance, restitution of title to real property, debts of state-owned enterprises to banks, savings restitution, the closure of the Ignalina Nuclear Power Plant (NPP) and privatisation of state property. All these are attributed to internal risks.

The risks are related to external factors that can impact the financial situation through pollution, higher financing costs, higher oil prices, etc.

In the field of energy, Lithuania inherited a huge and well developed energy infrastructure which was aimed at serving economy of a larger scale rather than that of domestic needs, and whose modernisation is investment and time consuming. Lithuania operates a well-developed system of natural gas transmission and distribution, and also a huge and significantly modern oil refinery (the only one in the Baltic States), as well as several big power generation plants, including the Ignalina NPP, which has two big reactors of $1.3 \mathrm{GW}$ capacity each. On the other hand, the power grid, gas and oil pipelines are connected only to Russian energy networks and all the primary energy resources are imported from the CIS. This understandably threatens Lithuanian economic security. The fact that 0.47 billion of $\mathrm{m}^{3}$ are supplied to Kaliningrad Region alleviates this threat.

Russia supplies gas from Belarus through the main Minskas - Vilnius gas pipeline and satisfies all the demand for gas. The gas supply network in Lithuania is also connected to Kaliningrad Region and Latvian gas pipeline network, which is not operational at the moment. There is one more gas pipeline to Belarus which is not operated at the moment either.

The Lithuanian gas network is not connected to Western networks, therefore, an alternative for natural gas supply is absent. The gas system of Lithuania should be merged with that of Poland (Western Europe), which would facilitate market relations in the gas sector and a common market. The gas pipeline connection between Lithuania and Poland would expand gas supply possibilities not only for Lithuania but also for Latvia and Estonia.

In 2000, the country's consumers used approx. 2.3 million tons of oil products. Lithuania has the only oil refinery in the Baltic States. The oil refinery satisfies almost 90 per cent of the demand for oil products of the country. The remaining part is imported. The local oil resources are scarce. The country recorded oil extraction of 4.2 million tons at the beginning of 2001.

The oil sector enjoys market relations. There are no restrictions on import, export, transit and trade of oil and oil products or quotas imposed by the country.

2001 marked the completion of the reconstruction of oil product stevedoring terminal which is owned by the AB "Klaipedos Nafta". That is a universal importexport terminal with stevedoring capacities of more than 7 million tons of different 
oil products.

One of the key energy policy goals of the state in decreasing dependence on the imports of energy resources is energy conservation and efficient use of primary energy resources as well as encouragement of producers and consumers for efficient consumption of local, renewable and other energy resources.

External dependence on energy resources can result in wide-range consequences. The most topical sector of dependence is gas, which is all imported. According to a forecast, the demand for gas will grow with the decommissioning of Unit II of the Ignalina NPP. Therefore, in order to diversify energy resources, one of the key goals is to develop an infrastructure for Lithuanian gas and power systems to be interconnected with those of the European Union.

The Lithuanian power market will also be gradually opened to international markets. Firstly, the integration into the common Baltic market has been foreseen, which is being developed at the moment, and further efforts will be made to integrate it into Western European and Scandinavian markets.

Certainly, the number of suppliers of energy resources predetermines their negotiating power, which is diminished to an insignificant extent by Lithuanian oil terminals and world energy prices. Even though Lithuania is capable of reducing their negotiating power, it is not capable of affecting the world price either as a consumer or a producer. Therefore, it is not by accident that the Law on the State Reserves of Crude Oil and Oil Products defines emergency in the energy sector as the period when the normal supply of energy resources or energy to energy enterprises and consumers is disrupted and their supply is interrupted to the extent that those disruptions make energy enterprises incapable of timely foreseeing and managing the situation on the basis of economic activity methods, and also as the period when emergency is announced as established by the Law. ${ }^{29}$ Thus, the impact on the prices of energy resources as a result of negotiating power and world prices on the domestic market is evident.

In the transport sector, the actions by the state and its approach towards this field of infrastructure predetermine not only the development of this sector but also the development of the entire economy.

The share of GDP from the transport sector had been increasing since 1996 and in 2000 it accounted for 8.3 per cent. About 5.1 per cent of total working population is employed in this sector.

International multimodal transport corridors of trans-European networks which were approved in the $2^{\text {nd }}($ Crete $)$ and $3^{\text {rd }}$ (Helsinki) European Transport Conferences and through which the main flows of cargo go, cross the Lithuanian territory. Indivisible components of multimodal transport corridors which make up TINA (Transport Infrastructure Needs Assessment) network in Lithuania are as follows: transport junction in Klaipeda Seaport, Vilnius, Kaunas and Palanga international airports, inland waters route Kaunas - Klaipėda.

Klaipeda Seaport is the only ice-free port operating all year round on the eastern coastline of the Baltic Sea.

\footnotetext{
${ }^{29}$ Law on the State Reserves of Crude Oil and Oil Products. "Valstybės žinios" (Lithuanian Official Gazette). No. 72, 17 July 2002.

${ }^{30}$ Lithuania's EU Accession Programme 2001-2003. http://www.euro.lt//lpnp/lit/index.htm, 6 August 2002 .
} 
The capacity of the railway network is basically satisfactory, however, the state of the railway infrastructure is rather poor and large investment is needed to improve the situation. Preparatory work is being done to renew the infrastructure by reconstructing a rail track, modernising alarm and telecommunication systems. Moreover, plans are made to build a rail track of the European standard gauge of the North South direction.

The infrastructure of Lithuanian airports and the air traffic control system are developed to a considerably satisfactory extent, however, the existing capacities are not fully used and the equipment of landing systems is outdated.

The Lithuanian Civil Aviation Administration and the Lithuanian Maritime Safety Administration were established in 2001, and an independent manager for aircraft accidents and incidents examination was appointed.

The Republic of Lithuania has ownership rights over infrastructural units.

The trends for developing transport infrastructure are regulated by Decision No 1692/96/EC of the European Parliament and the Council of 23 July 1996 on Community guidelines for the development of the trans-European transport network. This decision aims at ensuring that the trans-European transport network shall be established gradually by 2010 by integrating all transport infrastructure networks throughout the Community in accordance with the outline plans and specifications. ${ }^{30}$

Transport is known to be a very important part of socio-economic infrastructure. It directly predetermines the economic growth of the country due to international and domestic trade, tourism, and simultaneously contributes to the implementation of fundamental market principles of the Community, i.e. free movement of persons, people, goods, services, and capital.

A long-term goal of Lithuanian transport policy is to establish a system of transport which complies with the principles, goals and criteria that are set out in the guidelines for the trans-European transport network development on the territory of the EU and integrate into the trans-European transport network by developing transport corridors that cross the territory of the country.

In the field of macroeconomic stability, Lithuania has made significant achievements, and in principle it can be stated that Lithuania is a stable state from a macroeconomic point of view. This is shown by the indicators, such as fiscal deficit which is stabilised at 1.5 per cent of GDP and has not changed for several years in a row. On the other hand, every new government declares efforts to decrease the fiscal deficit. The public debt has also been stabilised.

All these positive changes have increased confidence in Lithuanian economy and its currency board arrangement (CBA), offering Lithuania a possibility of accessing international capital markets on increasingly better terms and conditions.

In the field of microeconomic stability or the level of industrial sectors, Lithuania has also made some achievements. Mobility of capital, labour force, land and other resource flows between sectors have been liberalised. The latter factor ensures microeconomic stability, which positively affects the economic growth. In this field, the threat of unemployment remains, since the unemployment rate is still very high over 10 per cent.

Therefore, there are practically no threats to economic security in the fields of macroeconomy, microeconomy or internally. The sore points of small and mediumsized enterprises (SMEs) in Lithuania could be defined as threats. They mostly mani- 
fest themselves not by the lack of state support to SMEs, but by the absence of efficient subcontractual relations between large companies and SMEs, the lack of efficient and favourable legal framework for the SMEs development, and significant part of added value generated by a large business sector.

The following internal and external threats to economic security of Lithuania can be identified. The internal threats are 1) unemployment rate, 2) low mobility of labour force, 3) low mobility of capital, 4) underdeveloped land market. To sum up, in order to mitigate the impact of these threats to economy, it is necessary to increase mobility of all kinds of resources in the internal resource markets.

The external threats include 1) big negotiating power of energy resource suppliers, 2) insufficient development of infrastructural sectors, 3) insufficient development of a model of foreign economic activities. The main function of a foreign economic activity model is provision of information on Lithuanian economic potential to foreign countries and institutions as well as keeping businessmen informed about the economic development abroad.

It is important to compile a list of indicators which define the economic security of the country. In other words, indicators which are important to the security of the functioning of the country's economic system should be identified. It is essential to understand that absolute security of the economic system is possible only under the circumstances of traditional economy. ${ }^{31}$ The interpretation of economic security under a closed and open economy is different in principle. Therefore, the list of the indicators that define the situation of the economic security of the country should be based on the concept of open economy. ${ }^{32}$

The indicators of economic security reveal efficiency of the functioning of the country's economic system.

\section{Conclusions}

pective of the diversity of definitions of economic security, the country's economic security can be defined as the capacity (i.e. political will, possibility, and ability) of the state and its entities to maintain balance between economic entities-systems, which is a key (necessary and sufficient) precondition for extended development of the state and its entities.

huanian strategy for threats to economic security ais predetermined by the characteristics that are common to small countries, i.e. small economy, open economy, and simple fixed exchange rate. These characteristics undoubtedly have a decisive impact on economic security.

neral national strategies are interrelated in the sense of centralisation/decentralisation of the decision-making process, intensity, scale and dynamism of threats, as well

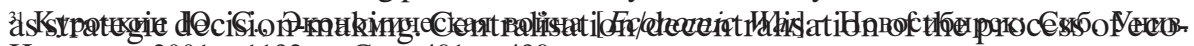

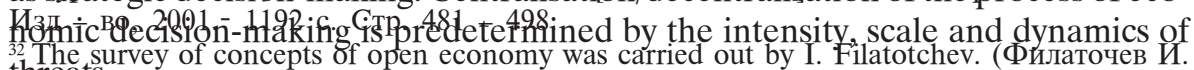

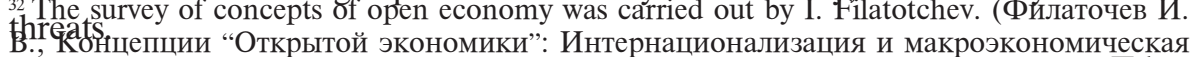

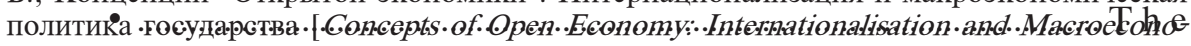

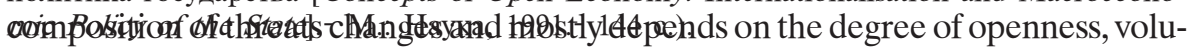
me and rate of economic growth.

huania has never clearly formulated and legitimised its national economic interests. Therefore, it is difficult to define threats to the economic security of the country. 